\title{
Value Relevance of Sustainability Report and Its Impact on Value of Companies
}

\author{
Desak Nyoman Sri Werastuti ${ }^{1, *}$ Anantawikrama Tungga Atmadja ${ }^{1}$ I Made Pradana
}

\author{
Adiputra $^{1}$ \\ ${ }^{l}$ Department of Economic and Accounting, Universitas Pendidikan Ganesha, Singaraja, Indonesia \\ *Corresponding author.Email: sri.werastuti@undiksha.ac.id
}

\begin{abstract}
This study aims to examine whether the sustainability report has value relevance for investors and affects the value of the company. Ohlson's multiple regression model is used as a method with 38 publicly listed companies in 2016-2019 as a sample. The results of the study show that investors use sustainability reports as value-added information in making investment decisions. Investors today are not only focused on short-term profits or company profits, but also the sustainability and long-term profits of the company in order to satisfy all stakeholders. The sustainability report made by the company is considered capable of being a material or aspect of consideration related to investments and helps indicate the long-term prospects of a company Therefore, regulators are expected to immediately issue adequate regulations regarding disclosure in sustainability reports.
\end{abstract}

Keywords: Sustainability report, Book value, Profit, company value

\section{INTRODUCTION}

In Indonesia, awareness of social responsibility has existed since 1999. However, it is still only mandatory for State-Owned Enterprises and the fact is that there are no rules on the form and content of reports. sustainability which should be reported so that the content is still voluntary. Based on data from the OJK as of 2016, only about 9 percent of all public companies listed on the IDX have issued sustainability reporting which refers to GRI Standards and disclosure is still voluntary. However, now through OJK Regulation No. 51/2017 regarding the implementation of sustainable finance for financial service institutions, issuers, and public companies, all issuers including financial institutions are required to issuesustainability reportinggradually starting from the 2019 reporting period.

According to signaling theory, the information disclosed by the company can provide a signal to investors. This signal is use investors to make investment decisions [1], [2], [3]. One of the financial information that is often disclosed by companies is financial information earnings. Information earnings generally empowered by investors in valuing a company because earnings allegedly able to evaluate the company's performance in the past, present, and can also predict the company's future performance [4].

However, using only information earnings is not enough for investors in making investment decisions in today's era. [5] and [6] explain that stakeholders need more information to make investment decisions because currently there is a phenomenon global warming which makes environmental and social issues important to consider. Frequently used non-financial information for studiesvalue- relevance is disclosure sustainability reporting or sustainability reports [7], [8]. Sustainability report is a report issued accountably to stakeholders by the company which includes the economic, environmental, social, and governance performance of the company's day-to-day operations. It can be said that in response to the phenomenonglobal warming, the company seeks to disclose its activities sustainability to stakeholders. Thus, disclosure sustainability reportingallegedly giving signals in the form of additional information to investors to assess the company [9], [10], [11]. Term sustainability report sometimes translated with the word Corporate Social Responsibility (CSR) report or Triple Bottom Line report. Thirdreport these contain the same meaning [12], [13], [14]. Sustainability reportingpromoted by an international and non-profit organization called Global 
Reporting Initiative (GRI) to companies around the world by making disclosure standards or guidelines sustainability reporting. Disclosure sustainability Besides being a signal for investors, it is also a form of accountability company to stakeholders according to stakeholder theory [15][16].

Many previous studies have tested value-relevance from sustainability reporting to the value of the company. In general, the value of a company can be seen from the value of its shares. However, the results of previous studies are still inconsistent. [13] analyzed value-relevance from sustainability reportingin Singapore. This study provides evidence that there is a positive relationship between sustainability reporting with share value. In line with that, the research of [19] also found that CSR reporting in Indonesia has a positive effect on firm value. In contrast, [17] and [18] found negative associations between the two in America. Different from the two previous studies, [19] and [20] stated that investors do not consider disclosure sustainability as value-relevance in companies in Brazil.

The inconsistency of the results of previous studies and the limited number of similar studies in developing countries as suggested by previous studies make this research important to re-examinevalue-relevance from sustainability reportingin the context of Indonesian companies. Indonesia is an important sample because it has biodiversity that must be maintained and a large enough population so that economic, social and environmental issues are a concern. In addition, Indonesia still does not require reportssustainability in the period before the provisions of POJK 51 of 2017 began to be stipulated by the government. Therefore, it becomes an interesting phenomenon to study in the period before and before the implementation sustainability report in Indonesia, especially in the period 2014 - 2017 to determine the effect of value relevance sustainability report in Indonesia in the early stages of implementing this regulation. With the adoption of GRI Standards The latest 2016 also makes this research even more interesting because there is no research in Indonesia that refers to GRI Standardslatest to count the amount of content disclosure sustainability which will be a novelty in this research. Tosustainability reporting the company in 2014 - 2015 still refers to GRI G4 Standards and only a few companies in 2016 have started to adopt the early implementation of the 2016 GRI Standards. Meanwhile, in 2017 companies have used GRI Standards 2016.

The purpose of this study is to test whether the information in the sustainability reporting issued by companies that have adopted GRI Standards 2016 has value-relevance for investors in making investment decisions and assessing a company. This research is expected to show results that are able to provideinsight for companies to commit to doing sustainability reporting as well as providing input to OJK to enforce obligations on public companies in relation to related disclosures sustainability reporting.

\section{METHOD}

This study collects information fromentities listed on the Indonesia Stock Exchange (IDX) from 2014 2017. The year 2014-2017 was chosen to see the effects of reporting sustainability by companies that were still voluntary before OJK issued POJK 51/2017regarding the obligation to report sustainability. Related Information sustainability reporting will be taken from sustainability report in the annual report, while information related to company value (from market value) will be obtained through the performance overview in the annual report and Factbook issued by the IDX. Sample selection using techniques purposive sampling by using several criteria including:

(i) companies or entities listed on the IDX from 2016-2019, (ii) companies disclosing sustainability reportingusing the GRI reference, and (iii) related information. These criteria aim that the information obtained is in accordance with the research objectives.

To test value-relevance from sustainability reporting [41] model was used in this research, as was also used by [32]. [41] model uses two equations or research models. The first research model analyzes the effect of the book value and the company's earning value on the company value (stock price times the number of shares outstanding) which is depicted in Figure 1.

The variable value of the company uses the market value proxy $(\mathrm{MVi}, \mathrm{t}+4)$ which is taken four months after the end of the financial year because companies usually issue annual reports along with sustainability reporting three or four months after the end of the financial year. The variable book value (BV) is proxied by the book value of the company's common stock. Value variable earnings (EARN) using sum income before there extra ordinary items. Thus, the regression equation of the first model is as follows:

$\mathrm{MVi}, \mathrm{t}+4=0+\alpha 1 \mathrm{BVi}, \mathrm{t}+\alpha 2 \mathrm{EARNi}, \mathrm{t}+3 \mathrm{EARNi}, \mathrm{t} \times \mathrm{NEGi}, \mathrm{t}+\varepsilon$ $\mathrm{i}, \mathrm{t}$

Information:

$\mathrm{MVi}, \mathrm{t}+4=$ market value in the fourth month after the company's financial year ends

$\mathrm{BVi}, \mathrm{t}=$ book value of common stock EARNi, $\mathrm{t}=$ earnings before extraordinaryitems

NEGi,t $=$ dumi variable $(1$ if earningsnegative company and 0 otherwise)

$\mathrm{i}, \mathrm{t}=$ term error

Then, the second research model isintended to examine the effect of sustainability reporting on the value of the company as well as testing value-relevance from sustainability. 


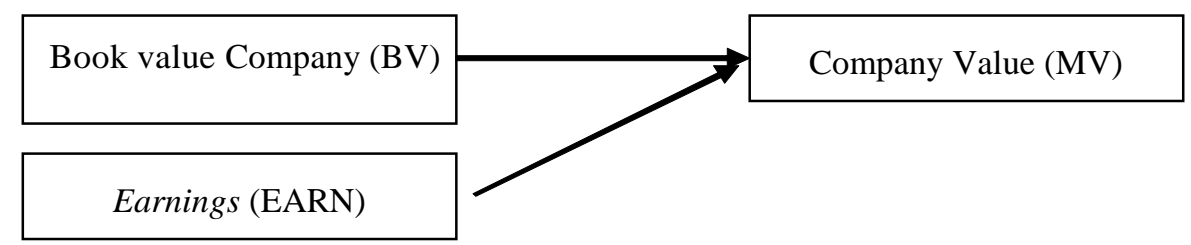

Figure 1. First Mode

Table 1. Examples of GRI Standards

\begin{tabular}{|l|l|l|l|}
\hline \multirow{2}{*}{ Universal Standards } & \multicolumn{3}{|c|}{ Topic-SpecificStandards } \\
\cline { 2 - 4 } & \multicolumn{1}{|c|}{ Economic } & \multicolumn{1}{|c|}{ Environmental } & \multicolumn{1}{c|}{ Social } \\
\hline $\begin{array}{l}\text { organization profile, } \\
\text { strategy, ethics and } \\
\text { integrity, governance, } \\
\begin{array}{l}\text { stakeholder } \\
\text { engagement-ment, and } \\
\text { reporting practice }\end{array}\end{array}$ & $\begin{array}{l}\text { Economic perfor- mance, } \\
\text { market presence, indirect } \\
\text { economic impacts, } \\
\text { procurement practice, anti- } \\
\text { corruption, and anti- } \\
\text { competitive behavior }\end{array}$ & $\begin{array}{l}\text { Energy, water, emissions } \\
\text { sions, biodiversity, } \\
\text { materials, environ- mental } \\
\text { compliance, etc }\end{array}$ & $\begin{array}{l}\text { Employment, } \\
\text { occupational health and } \\
\text { safety, non-dis- crime, } \\
\text { etc }\end{array}$ \\
\hline
\end{tabular}

Variable sustainability reporting (SR) is added to the research model which can be seen in Figure 2. Thus the equation of model (2) is:

MVi,t+4=0+ $+1 \mathrm{BVi}, \mathrm{t})+\alpha 2 \mathrm{EARNi}, \mathrm{t}+3 \mathrm{EARNi}, \mathrm{t} \times \mathrm{NEGi}, \mathrm{t}+$ SRi,t+ci,t

Information:

$\mathrm{MVi}, \mathrm{t}+4=$ market value in the fourth month after the company's financial year ends

$\mathrm{BVi}, \mathrm{t}=$ book value of common stock

EARNi,t = earnings before extraordinaryitems

NEGi,t = dumi variable ( 1 if earningsnegative company and 0 otherwise)

SR $\mathrm{i}, \mathrm{t}=$ amount items disclosure susstainability

$\mathrm{i}, \mathrm{t}=$ term error

The additional variable SR is the score of disclosure sustainability reporting which refers to the indicators set by GRI Standards 2016. The SR disclosure score is carried out using content analysis. GRI Standards 2016 developed by GRI ( Global Reporting Initiative) has two types of standards namely Universal Standards and Topic-Specific Standards. Universal Standards applies to all companies that empower GRI Standards as a reference or guidelines to make a report sustainability. Universal Standards containing foundation (contains basic reporting principles and how to use standards), general disclosures (contains company-related information and reporting practices sustainability), and management approach (contains a management approach conveying material topics).
Topic-Specific Standards contains threetopics namely economic, environmental, and social. Companies can choose relevant topics tobe disclosed in the report sustainability in accordance with the material topics specified in the management approach (see Table 1). For disclosure, companies can choose to disclose options Core (core) only or Comprehensive (complete). For the purpose of assessing the SR score based oncontent analysis, sustainability report companies for the period 2016-2019 that still use GRI G4 Standardsconverted to GRI Standards 2016 using the conversion guidelines that have been issued by GRI. SR score will be obtained throughcontent analysis by counting.

The number of items disclosed in the subtopic general disclosure, economic, environmental,and social. Model equations (1) and (2) use multiple regression analysis. From the model equations (1) and (2) it is expected that the variables BVi,t and EARNi,t will have a positive relationship with firm value $(\mathrm{MVi}, \mathrm{t}+4)$. Meanwhile, NEGi,t is expected to lead to an opposite or negative relationship with firm value $(\mathrm{MVi}, \mathrm{t}+4)$. Then, the SR variable should also have a positive effect on firm value $(\mathrm{MVi}, \mathrm{t}+4)$. Adjusted $\mathrm{R} 2$ is expected to increase from model (1) to model (2) because it means that investors perceive related information sustainability reporting that value-relevance and used in decision 


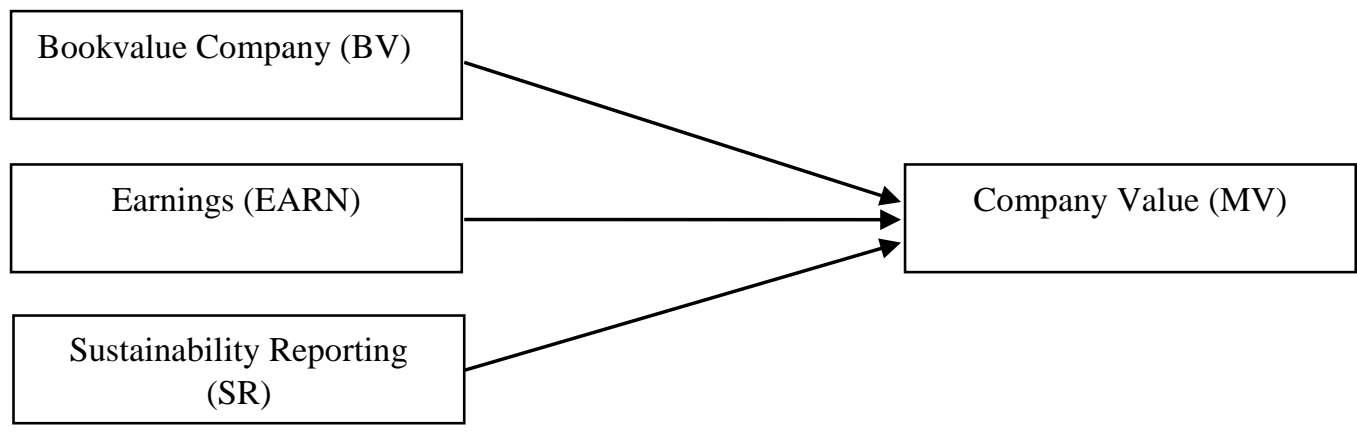

Figure 2. Second Model

Table 2. Operationalization of Variables

\begin{tabular}{l|l}
\hline \multicolumn{1}{|c|}{ Variable } & \multicolumn{1}{c}{ Definition } \\
\hline MV & Market value (number of shares outstanding $x$ share price) in the 4th month after the end of the financial \\
& year \\
BV & Company book value (total value of common stock) \\
EARN & Net income before extraordinary items \\
NEG & Dumi variable is equal to 1 if EARN is negative and equal to 0 otherwise \\
SR & Disclosure rate score Sustainability Reporting refers to the GRI indikator indicator standards \\
\hline
\end{tabular}

Table 3. Sample Selection

\begin{tabular}{|l|r|}
\hline Criteria & Amount Company \\
\hline A public company that has been listed on the IDX during 2016- 2019 & 599 \\
\hline Companies with incomplete annual reports in the 2016-2019 period & 494 \\
\hline $\begin{array}{l}(397) \\
97 \\
\text { Companies that do not use GRI standards in compilingsustainability reporting }\end{array}$ \\
\hline $\begin{array}{l}\text { The company does not have complete information and is not available on the } \\
\text { internet }\end{array}$ & 38 \\
\hline $\begin{array}{l}\text { Companies selected as research samples Number of observations with unbalanced } \\
\text { panel data }\end{array}$ & \\
\hline
\end{tabular}

making [41]. Table 2 presents a recapitulation of operational variables in this study.

\section{RESULTS \& DISCUSSION}

Total company observations from 2016-2019 that have sustainability reporting according to GRI Standards there are 129 observations from 38 companies. The process related to the observed sample selection can be seen in Table 3 .

Table 4 below presents a number of data characteristics. These characteristics include the average (mean), minimum, and maximum of each variable tested in this research.

Table 4. Descriptive Statistics

\begin{tabular}{|c|c|c|c|}
\hline Variable & Average & Minimum & Maximum \\
\hline MV & $62,427,369,000,000$ & $360,360,000$ & $437,854,997,000,000$ \\
\hline BV & $28,036.754$ million & $614,942.800 .000$ & $166,748,817,000,000$ \\
\hline EARN & $3,659,389,000,000$ & $-6,483,084,000,000$ & $28,997,141,000,000$ \\
\hline NEG & 0.1472868 & 0 & 1 \\
\hline SR & 1.851286 & 0.7545 & 3.2742 \\
\hline
\end{tabular}


In Table 4, the dependent variable, namely firm value (MV) has an average of (mean) 62,427,369 million rupiah. The highest company value in the sample is $437,854,997$ million rupiah owned by PT Telkom in 2017 and the lowest value is 360,360 million rupiah which is the company value of PT Bank Bumi Arta in 2016.

The distance between the highest and lowest values is quite far because the sample in research come from different industries. From a sample of 38 companies, 31 percent of them came from the banking/finance industry, 26 percent from the mining and oil and gas industry, $13 \%$ from the manufacturing industry, 11 percent from the construction industry, 8 percent from telecommunications companies, 5 percent from the plantation industry, and 5 percent from the transportation and heavy equipment industry. The value of the company can be affected through several factors, one of which is whether it comes from reporting sustainability which is the question in this research.

The first independent variable in the study is book value (BV) which is in the range of $614,942.8$ million rupiahs to $166.748,817$ million rupiahs and the average $28,036,754$ million. Based on the sample during 20162019, PT Bank BRI in 2019 had the highest book value and PT Bank Bumi Arta in 2018 had the lowest book value. Book value is influenced by the amount of paidup capital by shareholders. Based on the sample during 2016-2019, the average company in the sample is large because the average both $\mathrm{BV}$ and $\mathrm{MV}$ are above the median value $(19,945,534$ million rupiah and 13,377,067 million rupiah).

The second independent variable is the value of earnings (EARN). Average scoreearnings (EARN) which is the value of net income before extraordinary items which is $3,659,389$ million rupiah. In the research sample, the smallest EARN value of $-6,483,084$ million rupiah was owned by PT Bank Permata in 2018 meaning that PT Bank Permata could not show good performance because it suffered losses (earnings negative). PT Bank BRI recorded the highest earning value in 2019 of 28,997,141 million rupiah, which means that BANK BRI was able to show good performance. When viewed from the variableNEG, about 14.7 percent of the total study sample had a value net income negative (NEG). However, in the majority, Table 5. Average SR Score the companies in the sample have good profitability which is indicated by the value ofearnings (EARN) is positive.

Next, for the variable sustainability reporting (SR), the total score of SR has the lowest value of 0.7545 and the highest of 3.2472. PT Indocement Tunggal Prakarsa in 2014 had the highest total SR score. This is in line with the achievements of PT Indocement Tunggal Prakarsa which obtained The Most Impressive CDM Reporting from National Center for Sustainability Reporting in the same year. Of the three GRI indicator sectors Standard (economic, social, and environmental), the highest score was obtained from the environmental sector. The lowest SR score was owned by PT PP (Rumah Pembangunan) in 2015. Based on its annual report, PT PP has just adopted GRI Standards in making reports sustainability in 2017. PT PP has not disclosed the environmental sector in its report.

The full value of the SR variable if the company discloses all items in GRI Standards namely 4.87 (1.87 score for disclosure general disclosure (total disclosure general disclosure 56 itemsdivided by the number of items that have labels Coreas much as 33 items), one score for full disclosure in the economic sector, one score for full disclosure in the social sector, and one score for full disclosure in the environmental sector. From the results of descriptive statistics on the SR variable, the average SR disclosure score in the same companymop is still low with a score of 1.85 , but about $31 \%$ of companies from the observation data make full disclosure on the topic General Disclosure which is Core (33items). For economic topics of a total of 10 items disclosure, PT Bukit Asam in 2017 had the highest number of disclosures for economic topics, which disclosed 9 items. For environmental topics from 30 items disclosure, PT Semen Holcim in 2014 had the highest number of disclosing 26 items. For social topics from 40 items disclosure, PT Semen Holcim in 2016 had the highest number of disclosures of 30 items. This study uses 38 samples of companies that have implemented GRI Standard in the report sustainability, the banking industryis the industry that uses the most GRI Standard in the template to makesustainability report which is 33 percent. This is because the banking industry will be the first industry to be required to fully disclosesustainability reporting in 2020. GRI Standards

\begin{tabular}{|c|c|c|c|c|c|}
\hline Industry & $\begin{array}{c}\text { Average SR } \\
\text { score }\end{array}$ & $\begin{array}{c}\text { Average } \\
\text { General items } \\
\text { disclosure (max } \\
33 \text { items) }\end{array}$ & $\begin{array}{c}\text { Average } \\
\text { number of } \\
\text { disclosures } \\
\text { Economy (max } \\
10 \\
\text { items) }\end{array}$ & $\begin{array}{c}\text { Average } \\
\text { number of } \\
\text { disclosures } \\
\text { Social } \\
\text { (max } 40 \text { items) }\end{array}$ & $\begin{array}{c}\text { AverageAverage } \\
\text { number of } \\
\text { disclosures } \\
\text { Environment } \\
\text { (max } 30 \text { items) }\end{array}$ \\
\hline Banking/Finance & 1.71 & 34 & 3 & 10 & 3 \\
\hline Mining and Oil and & 2.04 & 31 & 5 & 13 & 10 \\
\hline
\end{tabular}




\begin{tabular}{|l|c|c|c|c|c|}
\hline Gas & & & & & \\
\hline Manufacture & 1.99 & 30 & 4 & 10 & 13 \\
\hline Construction & 1.65 & 29 & 4 & 9 & 3 \\
\hline Telecommunication & 1.52 & 29 & 3 & 8 & 3 \\
\hline $\begin{array}{l}\text { Transportation and } \\
\text { Heavy Equipment }\end{array}$ & 2.01 & 37 & 5 & 15 & 9 \\
\hline Plantation & 2.04 & 32 & 2 & 19 & 13 \\
\hline
\end{tabular}

is one of the standards that can be adopted for creating and compiling sustainability reporting which will be required by the OJK. The average SR score by industry is shown in Table 5.

The banking sector has the largest sample in the study, but the highest average SR scores come from the mining and oil and gas and plantation sectors. The lowest average SR score comes from the telecommunications sector.

Average number of disclosures the highest economic sector was obtained from the mining and oil and gas sector as well as transportation and heavy equipment. The highest average number of social sector disclosures was obtained from the plantation sector. The highest average number of environmental sector disclosures was obtained from the manufacturing and plantation sectors. When viewed from Table 5, it can be interpreted that industries that run in sensitive fields have disclosuressustainability more in the sensitive area.

Referring to the results of the descriptive statistics shown in table 5, the characteristics of the variables that are operationalized in this research are quite varied and come from companies with different industries. The highest value of the MV variable is owned by telecommunication companies, while the highest values of BV and EARN are owned by companies with a background in the financial industry and the value of the SR variable is owned by manufacturing companies.

The results of the multiple regression test run on the model equation (1) are presented in Table 6 Column 1. In accordance with the [41] model, the model equation (1) does not include the SR variable (Sustainability Reporting) because to see the contribution of the influence of SR to firm value (MV) is in the equation of the 2nd model.

Table 6. Regression Results

\begin{tabular}{|c|c|c|}
\hline Variable & (Model 1) MV & (Model 2) MV \\
\hline BV & $0.871^{\star * *}$ & $0.852^{\star \star \star}$ \\
\hline EARN & $2.66 \mathrm{e}-08^{\star \star \star}$ & $2.78 \mathrm{e}-08^{\star \star \star}$ \\
\hline $\mathrm{NEG}^{\star} \mathrm{EARN}$ & 7.60e-09 & $9.24 \mathrm{e}-09$ \\
\hline SR & & $0.075^{*}$ \\
\hline Constant & 0.988 & 1.016 \\
\hline $\mathrm{R} 2$ & 0.784 & 0.790 \\
\hline AdjustedR2 & 0.779 & 0.782 \\
\hline F-Value & $151.41^{\star \star \star}$ & $116.38^{* * *}$ \\
\hline IncrementalR2 & & 0.006 \\
\hline
\end{tabular}

According to the regression prediction in model 1 (Table 6 column 1), the results show that book value (BV) and earnings (EARN) has a positive and significant impact on firm value (MV). These results can be interpreted that with the higher book value andearnings of a company, the value of the company as measured by its market value will also increase. Interaction variables betweenearnings and dummy earnings negative (NEG*EARN) has no significant effect.

Based on the regression results, with Adjusted R2 model 1 which is worth 0.779 , it reflects that the three variables $\mathrm{BV}$, EARN, and NEG*EARN can explain 77.9 percent of the independent variable firm value (MV).

Result ofAdjusted This high R2 is also similar toprevious studies examining the topic value relevance on sustainability/ CSR reporting using the [21] model, namely [5] at 67.2 percent, [22] at 87.4 percent, [23] at 96 percent, and [4] at 75.1 percent. The value of the $F$ test model (1) also indicates that the variables BV, EARN, and NEG*EARN can jointly affect firm value with a significant level at the one percent level. The results of the regression model (1) can also prove that the financial information disclosed by the company such as the value ofearnings (EARN) and book value (BV) have value-relevancewhich can move stock prices and increase the market value of the company. These results are in line with research by [24], [25], and [26].

To see the effect sustainability reporting (SR), model (2) includes the SR variable in the equation. The results of the regression model (2) (Table 6 column 2) reflect that the SR variable has a positive and significant impact on firm value (MV) with a significance level of 
$10 \%$. In addition, model (2) hasAdjusted R2 is 0.782 , this is an increase of 0.003 from Adjusted R2 models (1).

Although the value of the increase inAdjusted R2 is very small, the $F$ value of the model (2) remained significant $(p<0.001)$. increase from Adjusted The R2 indicates that the information disclosed by the company through sustainability reporting have value-relevance which can help move stock prices and increase the market value of the company. If adjusted R2 no increase from model (1) to (2), it can be said that the information in the sustainability report don't give value-relevance which can affect the value of the company. Thus, it can be concluded from the regression results presented in Table 6 column 2, the question in this study is whethersustainability reporting affect the value of the company and have value- relevance for investors has been answered. In model (2) also showsbook value (BV) and earnings (EARN) has a positive and significant impact on firm value (MV). These results are in line with the results in model (1).From the results of this research, it was revealed that the information related to book value and earnings the company has a positive influence on the value of the company.

Companies that have valuebook value and earnings high market value based on the results of this study also has a high market value. This is in line with the research of [13] and [27]. Related Informationbook value and earnings including financial information that investors use to make investment decisions and ultimately can move the company's stock price [22], [26], [28].

The research results also found that sustainability reporting have a significant positive impact on the company's market value. In other words, the moreincrease disclosure level sustainability reporting, the greater the market value of the company. In addition, the information insustainability reporting considered to have value-relevance by investors to make investment decisions so as to move the company's stock price. Non-financial information such assustainability reporting that are widely expressed by many companies are starting to be considered by investors in making decisions. [5] and [6] explain that investors demand more information from a company to make investment decisions. This is related to the phenomenonglobal warming as well as biodiversity erosion which is popular in recent times, so that environmental and social issues are also important to consider. This is in line with the arguments of [29] and [30] which argue that investors are no longer focused on how to get short-term profits (only looking at profits), but investors consider how to get long- term profits by accommodating the wishes of investors.stakeholders. Just looking at profit does not guarantee the sustainability of the company in the long term [13], [27]. As a result, investors seek other information such as non-financial informationone of them sustainability reportingto be considered in assessing companies [22], [28].

This research provides results that are in line with several previous studies [31], [23], [32], [4] which found that sustainability/csr reporting contains relevant information related to decision making and making. The results of the study also indicate that for investors, the information contained in thesustainability report is useful information for making investment decisions. As issustainability reporting, investors can anticipate that a company will perform well in future periods [33], [34], [35], [36]. There are two theories used in this study to explain the influence between sustainability reporting and firm value, namely signaling theory [1], [37], [3] and stakeholder theory [38], [3].

According to the firm's signaling theory, which reveals sustainability reporting voluntarily intends to signal to investors that the company is carrying out economic, environmental and social related initiatives aimed at obtaininglong-term benefits [39], [40], [41]. The company voluntarily wishes to submitimpactof the company's operating activities to the environmental, social, and economic sectors. This signal is considered to make capital market participants or investors react positively to the company so that it makes investors interested in the company [42], [43]. If many investors are interested, for example by buying shares in a company, then this can move the company's stock price up. If there is an increase in the stock price, then the value of the company also increases. Another reason investors react positively is because investors can easily assess the company's risk profile on the information that has been submitted and expect good performance in the future. Other researchers who also use signaling theory in researching value-relevance from sustainability reporting namely [44], [39], and [32].

In addition to signaling theory to explain the effect of sustainability reportingon the value of the company there is also a theory stakeholders. [45] argues that stakeholders are a group or individual who has the capacity and authority to influence or be affected by the achievement of company goals. Stakeholders have the power to drive companies to operate according to their expectations [46], [47]. Thus, the company will strive to always achieve or obtain results that benefit all parties stakeholders [48], [49].

Sustainability report is a form of corporate operating responsibility for stakeholders so that stakeholders know what the company has done. In addition, [35] argue that there are sustainability report can be used as a means of corporate communication to stakeholders to enhance the company's positive image, build competitive advantage, and maintain good relations with the community. 
Thus, there is an expectation that the company's performance will increase so that it can affect the stock price which will ultimately increase the value of the company. In addition, studies conducted by [50] and [51] explained that by publishing sustainability reporting, the company will get several benefits, for example easier and faster access to obtain funding both internally and externally, a high and good reputation, good relations with stakeholders. stakeholders, increase competitive advantage (innovation and efficiency), as well as good financial performance. Other researchers who also use the theory stakeholders in researching value-relevance fromsustainability reporting namely [52], [39], and [32].

Overall, the results of this study add to the literature related value-relevance from sustainability reporting. The results of the study confirm the theory signaling and stakeholders as a reference in the discussion of this research.Based on this research sustainability reporting beneficial to the company because it can move the stock price so as to increase the value of the company. Agenda sustainability is actually an agenda proclaimed by the United Nations which is contained in the Sustainability Development Goal (SDGs) which requires all countries including Indonesia to preparework plans that support the fulfillment of the SDGs. The responsibility for fulfilling the SDGs is not only the responsibility of the government, but also the shared responsibility of all levels, including companies. Through POJK 51/2017, the government will require all issuers (banks to apply first in 2020) to report their sustainability- based businesses. Companies are also expected to compilesustainability reporting refers to internationally accepted standards, one of which is GRI Standards. If all public companies in Indonesia are committed to preparing reports sustainability then Indonesia can contribute to the full fulfillment of the SDGs and the impact will be felt not only for companies but also for stakeholders.

\section{CONCLUSION}

Through the empowerment of the multiple regression model, this study shows results that can provide empirical evidence that sustainability reporting has an influence on the value of the company so that it can be said sustainability reporting have the information value-relevance for investors to make investment decisions.

Sustainability reports made by companies are considered capable of becoming material or aspects of consideration related to investment and helping to show the long-term prospects of a company. Related to this, these results are also in line with the phenomenon that investors are currently not only putting their focus on short- term profits or company profits, but they are currently also looking at the sustainability and long-term profits of a company in order to satisfy all stakeholders. This is also because current profits cannot guarantee the sustainability of the company in the future. Furthermore, research is able to bring results that also strengthen the theory signaling and theory stakeholders in explaining the effect sustainability reporting to company value.

Company voluntary information presented in sustainability reporting considered to be a good signal. This information can be clearly received by investors in assessing a company and is considered a strong commitment by the company to investors stakeholders. Existence sustainability report can also be interpreted as the company's efforts to provide a positive image so that a good relationship can be established with the entire community. The novelty of this research is the use of the GRI . indicator Standards the latest 2016 as a proxy sustainability reporting.

In relation to the results of this study, the government, especially the regulators, is expected to immediately launch adequate regulations regarding disclosure in public disclosuressustainability report. This is so that investors or potential investors can make a more in-depth assessment of the performance and performance of a company and its sustainability. In addition, with the obligation regarding the company's sustainability, it is hoped that the market can give more value to companies with adequate information, and ultimately have an impact on a more transparent economic situation to the public.

There are several limitations encountered in this study. First,content analysis carried out in the process of calculating the disclosure score sustainability reporting inseparable from the subjective nature. Second, the score obtained for disclosuresustainability reporting only by quantity items disclosed have not been based on the quality or depth of disclosure. Third, the research sample is not disaggregated by industry which may influence the amount/topic of disclosure sustainability reporting.Thus, future research should measure the depth or quality of disclosure sustainability so it's not just based on quantity or quantity items.

\section{REFERENCES}

[1] J. Ahn, "Corporate Social Responsibility Signaling, Evaluation, Identification, and Revisit Intention among Cruise Customers," J. Sustain. Tour., vol. 27, no. 11, pp. 1634-1647, [Online]. Available: https://doi.org.

[2] A. Casey and L. Schaefer, "A narrative inquiry into the experience of negotiating the dominant stories of physical education: living, telling, retelling and re-living," Sport. Educ. Soc., vol. 21, no. 1 , pp. 114-130, 2016, doi: 10.1080/13573322.2015.1108300.

[3] G. Michelon and M. Rodrigue, "Demandfor 
CSR: Insights from Shareholder Proposals," Soc. Environ. Account. J., vol. 35, no. 3, pp. 157-175, doi: 10.1080/096916.

[4] D. Narullia and B. Subroto, "Value Relevance of Accounting Information and Corporate Social Responsibility in Indonesia and Singapore," $J$. Manag. Appl., vol. 16, no. 1, pp. 9-19, 2018, doi: 10.21776/ub.jam.2018.016.01.02.

[5] S. Berthelot, M. Coulmont, and Serret, "Do Investors Value Sustainabiliity Reports? A Canadian Study," Corp. Soc. Responsib. Environ. Manag., vol. 19, no. 6, pp. 355-363, doi: $10.1002 / \mathrm{csr} .285$.

[6] R. Edgeman, J. Eskildsen, and A. Neely, "Translating Triple Top Line Strategy into Triple Bottom Line Performance," Meas. Bus. Excell., vol. 19, no. 1, pp. 1-15, doi: 10.1108/MBE-12-2014-0054.

[7] D. S. Dhaliwal, O. Z. Li, A. Tsang, and Y. G. Yang, "Voluntary Non-financial closure and the Cost of Equity Capital: The Initiation of Corporate Social Responsibility Reporting.The," Account. Rev., vol. 86, no. 1, pp. 59-100, [Online]. Available: https://doi.

[8] F. Verbeeten, R. Gamerschlag, and K. Möller, "Are CSR Disclosures Relevant for Investors?," Empir. Evid. from Ger. Decis., vol. 54, no. 6, pp. 1359-1382, [Online]. Available: https://doi.org/10.1108/.

[9] T. Kaspereit and K. Lopatta, "The Value Relevance of SAM's Corporate Sustainability Ranking and GRI Sustainability Reporting in the European Stock Markets," Bus. Ethics Eur. Rev., vol. 25, no. 1, pp. 1-24, [Online]. Available: https://doi.org/10.1111/.

[10] N. E. Landrum and B. Ohsowski, "Identifying Worldviews on Corporate Sustainability: A Content Analysis of Corporate Sustainability Reports," Bus. Strateg. Environ., vol. 27, no. 1, pp. 128-151, doi: 10.1002/bse.1989.

[11] A. Uyar, "Stand-Alone SustainabilityReporting Practices in an Emerging Market: A Longitudinal Investigation," J. Corp. Account. Financ., vol. 28, no. 2, pp. 62-70, [Online]. Available: https://doi.org/10.1002/.

[12] U. Lenka and Tiwari, "Achieving Triple'P' Bottom Line through Resonant Leadership: An Indian Perspective," Int. J. Product. Perform. Manag., vol. 65, no. 5, pp. 694-703, doi: 10.1108/IJP-PM-02-2015-0023.

[13] L. Loh, T. Thomas, and Y. Wang, "Sustainability Reporting and Firm Value: Evidence from Singapore-Listed Companies," Sustainability, vol. 9, no. 11, pp. 1-12, 2017, doi: $10.3390 / \mathrm{su} 9112112$.
[14] M. A. O. D. Santos, G. Svensson, and C. Padin, "A "Fivefold Bottom Line," Approach Implement. Report. Corp. Efforts Sustain. Bus. Pract. Environ. Qual., vol. 25, no. 4, pp. 421430, doi: 10.1108/MEQ-04-2013-0026.

[15] N. T. Dai, F. Du, S. M. Young, and G. Tang, "Seeking Legitimacy through CSR Reporting," Evid. from China.Journal Manag. Account. Res., vol. 30, no. 1, pp. 1-29, [Online]. Available: https://doi.

[16] H. H. Huang, L. Sun, and T. R. Yu, "Socially Responsible Firms Less Likely to Expatriate?," An Exam. Corp. Inversions.The J. Am. Tax. Assoc., vol. 39, no. 2, pp. 43-62, doi: 10.2308/atax-51790.

[17] N. Bhalla and H. K. Overton, "Examining cultural impacts on consumers' Environmental CSR Outcomes," Corp. Commun. An Int. J., vol. 24, no. 3, pp. 569-592, [Online]. Available: https://doi.

[18] D. El-Bassiouny and N. El-Bassiouny, "Corporate Governance and CSR Reporting: A Comparative Analysis between Top-Listed Firms in Egypt, Germany and the USA," Manag. Environ. Qual., vol. 30, no. 1, pp. 116136, doi: 10.1108/MEQ-12-.

[19] M. M. Miralles-Quirós, J. L. Miralles-Quirós, and L. M. V Gonçalves, "The ValueRelevance of Environmental, Social, and Governance Performance," The Brazilian Case.Sustainability, vol. 10, no. 3, pp. 574-588, doi: 10.3390/su10030574.

[20] A. Sobczak and L. C. Martins, "TheImpact and Interplay of National and global CSR Discourses: Insights from France and Brazil," Corp. Gov., vol. 10, no. 4, pp. 445-455, doi: 10.1108/14720701011069678.

[21] J. A. Ohlson, "Earnings, Book-Values, and Dividends in Equity Valuation.Contemporary Accounting Research, 11(2),661-687.' [Online]. Available: https://doi.

[22] P. Cardamone, C. Carnevale, and F. Giunta, "The value relevance of social reporting: Evidence from listed Italian companies," $J$. Appl. Account. Res., vol. 13, no. 3, pp. 255-269, [Online]. Available: https://doi.org/.

[23] M. D. Klerk and C. D. Villiers, "The ValueRelevance of Corporate Responsibility Reporting: South African Evidence," Meditari Account. Res., vol. 20, no. 1, pp. 21-38, [Online]. Available: https://.

[24] H. Brown-Liburd and V. Zamora, "Role of Corporate Social Responsibility (CSR) Assurance in Investors' Judgments When Managerial Pay is Explicitly Tied to CSR 
Performance," AU-DITING A J. Pract. Theory, vol. 34, no. 1, pp. 75-96, 2015, doi: doi.org/10.2308/.

[25] A. Jain, P. K. Jain, and Z. Rezaee, "ValueRelevance of Corporate Social Responsibility: Evidence from Short Selling," J. Manag. Account. Res., vol. 28, no. 2, pp. 29-52, [Online]. Available: https://doi.

[26] T. Kumar, "Achieving Sustainable Development through Environment Accounting from the Global Perspective: Evidence from Bangladesh," Asian J. Account. Res., vol. 2, no. 1, pp. 45-61, doi: 10.1108/AJAR-2017-.

[27] N. Petcharat and M. Zaman, "sustain- ability Reporting and Integrated Reporting Perspectives of Thai-Listed Companies.Journal of Financial," Report. andAccounting, vol. 17, no. 4, pp. 671694, doi: 10.1108/JFRA-09-2018-0073.

[28] K. Sridhar, "Corporate Conceptions oftriple Bottom Line Reporting: An Empirical Analysis into the Signs and Symbols Driving this Fashionable Framework.Social ResponsibilityJournal," vol. 8, no. 3. pp. 312326, doi: 10.1108/17471111211247901.

[29] K. P. Nielsen and R. W. Noergaard, "CSRand Mainstream Investing: A New Match? - An Analysis of the Existing ESG Integration Methods in Theory and Practice and the Way Forward,Journal of Sustainable Finance \&," Investment, vol. 1, no. 3-4, pp. 209-221, doi: doi.org/10.10.

[30] P. Withisuphakorn and P. Jiraporn, "Effect of Firm Maturity on Corporate Social Responsibility (CSR): Do Older Firms Invest More in CSR?," Appl. Econ. Lett., vol. 23, no. 4, pp. 298-301, doi: 10.1080/13504851.2015.1071464.

[31] M. Ibrahim, E. Z. Solikahan, and A. Widyatama, "Company Characteristics, Wide Disclosure of Corporate Social Responsibility, and Company Value.Journal of," Multiparadigm Account., vol. 6, no. 1, pp. 99-106, [Online]. Available: https://doi.org/10.18202/.

[32] N. Laskar, "Impact of Corporate Sussustainability Reporting on Firm Performance: An Empirical Examination in Asia," J. Asia Bus. Stud., vol. 12, no. 4, pp. 571-593, [Online]. Available: https://doi.

[33] R. Ameer and R. Othman, "Sustainability Practices and Corporate Financial Performance: A Study based on the Top Global Corporations," J. Bus. Ethics, vol. 108, no. 1, pp. 61-79, [Online]. Available: https://doi.

[34] D. Greiling and B. Grüb, "Sustainability Reporting in Austrian and German Local Public
Enterprises," J. Econ. Policy Reform, vol. 17, no. 3, pp. 209-223, doi: 10.1080/17487870.20.

[35] L. Massa, F. Farneti, and B. Scappini, "a Sustainability Report in a Small to Medium Enterprise: Process and Consequences," Meditari Account. Res., vol. 23, no. 1, pp. 6291, doi: 10.1108/MEDAR-02-2014-0030.

[36] S. Waworuntu, M. Wantah, and T. Rus- manto, "CSR and Financial Performance Analysis: Evidence fromTop ASEAN Listed Companies," Procedia-Soc. Behav. Sci., vol. 164, pp. 493500, 2014, doi: 10.1016/j.

[37] R. C. Y. Chen and C. H. Lee, "The Influenceof CSR on Firm Value: An Application of Panel Smooth Transition Regression on Taiwan," Appl. Econ., vol. 49, no. 34, pp. 3422-3434, doi: 10.1080/00036846.2016.1262516.

[38] C. Kim, J. Kim, R. Marshall, and Afzali, "Stakeholder Influence, Institutional Duality, and CSR Involvement of MNC Subsidiaries," $J$. Bus. Res., vol. 91, pp. 40-47, [Online]. Available: https://doi.

[39] C. Kuzey and A. Uyar, "Determinantsof Sustainability Reporting and Its Impact on Firm Value: Evidence from the Emerging Market of Turkey," J. Clean. Prod., vol. 143, pp. 27-39, doi: 10.1016/j.jclepro.2016.12.153.

[40] A. S. L. Lindawati and M. E. Puspita, "Corporate Social Responsibility: Implications of Stakeholder and Legitimacy Gap in Improving Company Performance," $J$. Multiparadigm Account., vol. 6, no. 1, pp. 157174, [Online]. Available: https://doi.

[41] J. P. Naughton and C. Wang, "through Corporate Accountability Reporting," $J$. Account. Econ., vol. 60, no. 1, pp. 56-72, doi: 10.1016/j.jacceco.2015.03.001.

[42] R. P. Guidry and D. M. Patten, "Market Reactions to the First-Time Issues of Corporate Sustainability Reports: Evidence that Quality Matters," Sustain. Accounting, Manag. Policy J., vol. 1, no. 1, pp. 33-50, doi: $10.1108 / 20408021011059214$

[43] D. Cormier, I. M. Gordon, and M. Magnan, "Corporate Ethical Lapses: Do Markets and Stakeholders Care?Management Decisions.".

[44] J. H. Grenier, "Understanding and Contributing to the Enigma of Corporate Social Responsibility (CSR) Assurance in the United States," Audit. A J. Pract. Theory, vol. 34, no. 1, pp. 97-130, [Online]. Available: https://doi.

[45] K. Godker and L. Mertins, "CSR Disclosure and Investor Behavior: A Proposed Framework and," Res. Agenda.Behavioral Res. Account., 
vol. 30, no. 2 , pp. $37-53$, doi: $10.2308 /$ bria51976.

[46] S. N. Khan, "Making Sense of the Black Box: An Empirical Analysis Investigating Strategic Cognition of CSR Strategists in a Transitional Market," J. Clean. Prod., vol. 196, pp. 916-926, doi: $10.1016 / \mathrm{j}$.

[47] M. Nekhili, H. Nagati, T. Chtioui, and A. Nekhili, "Gender-Diverse Board and the Relevance of Voluntary CSR Reporting," Int. Rev. Financ. Anal., vol. 50, pp. 81-100, [Online]. Available: https://doi.

[48] H. A. Rangkuti, H. R. Yuliantoro, and Yefni, "Which is More Important Sustainability Report or Profit for Plantation Companies?.Journal of Multiparadigm Accounting," vol. 10, no. 2. pp. 365-378, doi: 10.18202/jamal.2019.08.10021.

[49] J. Wrana and J. R. Diez, "Multinational Enterprises or the Quality of Regional Institutions - What Drives the Diffusion of Global CSR Certificates in a Transition Economy?," Evid. from Vietnam. J. Clean. Prod., vol. 186, pp. 168-179, doi: 10.1016/j.jcle-.

[50] K. K. Inger and B. Vansant, "Market Valuation Consequences of Avoiding Taxes While also Being Socially Responsible," J. Manag. Account. Res., vol. 31, no. 2, pp. 75-94, [Online]. Available: https://doi.

[51] J. P. Naughton, C. Wang, and I. Yeung, "Sentiment for Corporate Social Performance," Account. Rev., vol. 94, no. 4, pp. 401-420, [Online]. Available: https://doi.

[52] V. J. Clout and R. J. Willett, "Earnings in Firm Valuation and Their Value Relevance," $J$. Contemp. Account. Econ., vol. 12, no. 3, pp. 223-240, doi: 10.1016/j.jcae.2016.09.005. 